\title{
RESEARCH
}

Open Access

\section{Engineering banana endosphere microbiome to improve Fusarium wilt resistance in banana}

\author{
Yupei Liu', Aiping Zhu'², Hongming Tan², Lixiang $\mathrm{CaO}^{2^{*}}$ and Renduo Zhang ${ }^{1 *}$ (D)
}

\begin{abstract}
Background: Plant microbiome highlights the importance of endosphere microbiome for growth and health of the host plant. Microbial community analysis represents an elegant way to identify keystone microbial species that have a more central position in the community. The aim of this study was to access the interactions between the keystone bacterial species and plants during banana Fusarium wilt process, by comparing the endophytic bacterial and fungal community in banana roots and shoot tips during growth and wilting processes. The keystone bacterial species were isolated and further engineered to improve banana wilt resistance.
\end{abstract}

Results: Banana endosphere microbiome structure varied during plant growth and wilting processes. Bacterial and fungal diversity in the shoot tips and roots increased with the development of the banana plantlets. The bacterial groups belonging to the Enterobacteriaceae family with different relative abundances were detected in all the samples. The Klebsiella spp. might be the keystone bacteria during the growth of banana plantlets. The relative abundance of Fusarium associated with the wilt disease did not increase during the wilting process. The endophytic Enterobacteriaceae strains Enterobacter sp. E5, Kosakonia sp. S1, and Klebsiella sp. Kb were isolated on Enterobacteriaceae selective medium and further engineered by expressing 1-aminocyclopropane-1-carboxylate (ACC) deaminase on the bacterial cell walls (designated as E5P, S1P, and KbP, respectively). Pot experiments suggested that plants inoculated with strains E5, E5P, S1, and S1P increased resistance to the Fusarium wilt disease compared with the controls without inoculation, whereas the Klebsiella inoculation (Kb and KbP) did not increase the wilt resistance. Compared with the inoculation with the wild strains E5 and S1, the inoculation with engineered strains E5P and S1P significantly increased wilt resistance and promoted plant growth, respectively. The results illustrated that the keystone species in the banana microbiome may not be dominant in numbers and the functional role of keystone species should be involved in the wilt resistance.

Conclusion: The ACC deaminase activity of engineered bacteria was essential to the Fusarium wilt resistance and growth promotion of banana plants. Engineering keystone bacteria in plant microbiome with ACC deaminase on the cell walls should be a promising method to improve plant growth and disease resistance.

Keywords: ACC, Banana, Endophyte, Enterobacter, Ethylene, Fusarium wilt

\footnotetext{
* Correspondence: caolssclx@163.com; zhangrd@mail.sysu.edu.cn

${ }^{2}$ School of Life Sciences, Guangdong Provincial Key Laboratory for Climate

Change and Natural Disaster Studies, Sun Yat-sen University, Guangzhou,

China

${ }^{1}$ School of Environmental Science and Engineering, Guangdong Provincial

Key Laboratory of Environmental Pollution Control and Remediation

Technology, Sun Yat-sen University, Guangzhou, China
}

(c) The Author(s). 2019 Open Access This article is distributed under the terms of the Creative Commons Attribution 4.0 International License (http://creativecommons.org/licenses/by/4.0/), which permits unrestricted use, distribution, and reproduction in any medium, provided you give appropriate credit to the original author(s) and the source, provide a link to the Creative Commons license, and indicate if changes were made. The Creative Commons Public Domain Dedication waiver (http://creativecommons.org/publicdomain/zero/1.0/) applies to the data made available in this article, unless otherwise stated. 


\section{Background}

Banana (Musa spp.) is an important fruit and cash crop in the sub-tropic and tropic regions [1]. However, banana production is constrained by many soil-borne pests [2], and Fusarium wilt is one of the most destructive diseases of banana $[2,3]$. The pathogenic Fusarium oxysporum f. sp. cubense (FOC) infects banana roots, and the infection progresses into vascularized portions of the rhizome in susceptible banana cultivars [2,3]. Tyloses, gums, and gels are produced in xylem lumena in response to Fusarium infection, and the affected xylem becomes reddish and eventually pugged, impeding water and nutrient transport [3]. The production of fusaric acids by FOC causes yellowing of leaf lamina [3]. FOC can survive in the soil for decades and disseminate in diverse ways (i.e., infecting soil, surface water, plants, and others). With limited options to manage the Fusarium wilt, resistant cultivars are the only consistently effective tool for controlling the disease in pathogen infested soils. Nevertheless, resistant cultivars are commercially unacceptable, scarce, and nonproductive [3].

The tissue-culture technique has been widely employed for germplasm conservation and rapid clonal propagation of banana. By producing tissue-culture plants axenically in greenhouse and field, beneficial and nonpathogenic endophytes are excluded together with pests [4]. Manipulation of the plant microbiome can increase agricultural production, reduce the incidence of plant diseases, and reduce chemical inputs, resulting in more sustainable and effective agricultural practices [57]. Banana endophytes are beneficial to the host plant, including growth promotion, and biological control against plant viruses, nematode, and plant weevil [8-11]. Managing the banana endosphere microbial consortia isolated from the plant's own microbiome may improve plant resistance to pathogens [12]. The traits make endophytes be potential natural resources for biological control of banana pests. Nonetheless, banana plants inoculated with endophytes are still infested by FOC in the field [10]. Genetically modified endophytes confer new characteristics of disease resistance to plants without direct manipulation of the host plant genome [13].

Banana tissue cultures are initiated from suckerenclosed shoots after extensive surface sterilization and under aseptic conditions. Therefore, the tissue-cultured plantlets of banana may contain the crucial microbial members provided by shoot tips. The vertical transmission progress can select for crucial microbiota in banana, and the microbial species become a core component of the host plant microbiome [14, 15].

In plants, ethylene serves as signals for recognition of microbes [16]. The ethylene level during compatible or susceptible disease interactions may affect the development of disease symptoms [17, 18]. Bacterial 1-aminocyclopropane-1-carboxylate (ACC) deaminase can cleave ACC from plants, reduce the ethylene level in plant host, and thus promote plant growth [19]. Therefore, it is possible to improve the resistance to banana Fusarium wilt and plant growth, using engineered crucial microbiomes by expressing ACC deaminase on cell walls.

Deciphering the banana core microbiome and their correlations with host plant and pathogens is critical to utilize the microbiome to enhance plant growth and health. The objective of this study was to investigate the interactions between plants, fungi, and bacteria during wilting process using tissue-cultured plantlets (i.e., roots and pseudostems) and healthy and wilting mature banana plants. Based on comparative analyses of the banana endosphere microbiomes, subsequent functions of engineered crucial Enterobacteriaceae were evaluated for growth promotion and Fusarium wilt suppression of banana.

\section{Methods \\ Sample collection and DNA extraction}

Banana samples were collected from a banana plantation in the suburbs of Guangzhou, China $\left(22^{\circ} 55^{\prime} 238^{\prime \prime} \mathrm{N}\right.$, $\left.113^{\circ} 31^{\prime} 053^{\prime \prime} \mathrm{E}\right)$. These domesticated banana plants are dependent on propagation via cloning, either by using suckers and cuttings taken from the underground stem or through modern tissue culture. Most banana plantlets are produced by modern tissue culture. The transmission of microbiota to the progeny represents a way to ensure the presence of beneficial symbionts within the habitat. The banana symbiotic microbiota may transmit from shoot tips to explants and to mature plants. The samples in different growth stages (i.e., explants and healthy and wilting mature plants) were collected and analyzed simultaneously to avoid the sequencing deviation from different sequencing condition.

To determine crucial microbial members proliferated in plant tissues during the growth stages and wilting development, the pseudostems and roots of banana explants (Musa sp., AAA, Giant Cavendish cv. Baxi) on Murashige and Skoog (MS) basal medium supplemented with $5 \mathrm{~m} / \mathrm{L}$ of benzyl aminopurine (BAP) (designated as Sstem and Sroot, respectively, $n=5$ ) from Guangzhou Academy of Agricultural Sciences were collected for DNA extraction. Suckers of healthy and wilting mature plants (Musa sp., AAA, Giant Cavendish cv. Baxi) were collected from the banana plantation in the suburbs of Guangzhou, China (22 $\left.55^{\prime} 238^{\prime \prime} \mathrm{N}, 113^{\circ} 31^{\prime} 053^{\prime \prime} \mathrm{E}\right)$. The banana suckers were uprooted, the external leaf sheaths were removed, and the shoot tips $(10-15 \mathrm{~mm})$ with almost half shoot and corm tissues were excised aseptically. The shoot tips $(0.1 \mathrm{~g})$ were used for DNA extraction. The plant roots were collected in plastic bags, 
washed with tap water, and surface sterilized within $4 \mathrm{~h}$ [20]. The surface sterilized roots $(0.1 \mathrm{~g})$ were used for DNA extraction. Shoot tips and roots of healthy mature plant in the field (designated as Btip and Broot, respectively, $n=5$ ), shoot tips and roots of wilting plants (designated as Wtip and Wroot, respectively, $n=5$ ), and shoot tips and roots of plants adjacent to the wilting plants but without wilting symptoms (designated as Htip and Hroot, respectively, $n=5$ ) were employed for total DNA extraction using E.Z.N.A. HP Plant DNA Kit (Omega) according to the manufactures' protocol [20].

\section{Amplicon generation and Illumina MiSeq sequencing} The fungal primers ITS3 (5'-GATGAAGAACGYAGYRAA-3') and ITS4 (5'-TCCTCCGCTTATTGATATGC-3') targeting ITS2 $r R N A$ genes were adopted to analyze fungal community [21]. The bacterial primers S17 (5'-CCTACGGGNGGCWGCAG-3') and A21 (5'-GACTACHVGGGTATCTAATCC-3') towards the bacterial $16 \mathrm{~S}$ rRNA genes V3-V4 hyper variable region were selected for bacterial community analysis [22]. The sequencing libraries were generated following the previous methods [20]. The library quality was assessed with the Nanodrop2000c (Thermo Scientific, USA) according to the manufacturer's instructions. The libraries were further sequenced by Genewiz Co. Ltd. (Suzhou, China) on Illumina MiSeq platform.

Raw sequences were merged by overlapping pairedend reads using FLASH software ( $v$ 1.2.7) [23]. The clean tags were obtained with the previous methods [24]. The UNITE database version 6 for Quantitative Insights into Microbial Ecology (QIIME) was used as a reference file for operational taxonomic unit (OTU) picking and community diversity analyses [22]. The tags with chimera were removed using UCHIME Algorithm $[25,26]$. The effective sequences were grouped into OTUs using the UPARSE-OTU and UPARSE-OTUref algorithms of UPARSE software package at $97 \%$ sequence similarity (Uparse v7.0.1001) [27]. Finally, the Ribosomal Database Project (RDP) multiclassifier was used to define indicator species and assign representative sequences to the phylum and genus levels [28]. All the sequencing data and raw reads generated during this study were deposited in GenBank under the accession numbers of SRP055897 (16S) and SRP061527 (ITS).

\section{Isolation of core symbiotic bacteria and construction of surface displaying plasmids}

The surface sterilized shoot tips were cut into small pieces (about $5 \times 5 \mathrm{~mm}$ ) and placed onto selective Eosin-Methylene Blue (EMB) medium with $2.0 \%$ agar. The shoot tip samples were incubated at $28^{\circ} \mathrm{C}$ for 7 days for bacterial colony formation. The colonies were purified, identified, and transformed with surface displaying plasmids. The 16S rRNA gene sequences of isolated strains have been deposited in the NCBI GenBank database under the accession numbers of KY800390, KY8003901, and KY8003902. The surface displaying plasmids, consisting of promoter sequences from Enterobacter cloacae, ice nucleation protein-N gene inaK-N, ACC deaminase gene (acdS JQ646055), and pUC57, were constructed with the previous methods [29, 30] (Additional file 1: Figure S1). The plasmid was further transformed into isolated Enterobacteriaceae strains using BTX ECM 399 electroporators under the following conditions: $2.0 \mathrm{kV}, 25 \mu \mathrm{F}, 200 \Omega$, and $2.5 \mathrm{~ms}$. Cells harboring the recombinant plasmid were grown in Luria-Bertani (LB) medium with $500 \mu \mathrm{g} \mathrm{mL}^{-1}$ ampicillin for 2 days. The cells were collected for determination of ACC deaminase activity by measuring the amount of $\alpha$-ketobutyrate released [31]. Toluene was used to increase cell permeability by dissolving the lipid structure of cell envelope, which increased membrane fluidity.

\section{Biocontrol experiments}

The indole-3-acetic acid (IAA) produced by endophytic bacteria in LB medium or LB medium supplemented with tryptophan $\left(200 \mu \mathrm{g} \mathrm{mL}^{-1}\right)$ was determined using the colorimetric method with Salkowski reagents [32]. The antagonistic activity of endophytic bacteria to Fusarium wilt pathogen was evaluated from plate confronting tests on banana pseudostem extract medium [33]. Endophytic bacterial sensitivity to fusaric acid $\left(100 \mu \mathrm{g} \mathrm{mL}^{-1}\right)$ was rated to be tolerant, moderately tolerant, and intolerant according to the inhibition percentages of fusaric acid by $0-40 \%, 41-80 \%$, and $81-100 \%$, respectively [34]. Strains tolerant to the concentration were rated as insensitive strains. Each treatment of the experiments was performed in triplicate.

Soil samples were collected from the banana plantation of Guangzhou, air dried, and sieved $(5 \mathrm{~mm})$. The soil was light gravel soil with texture of sandy loam $(68 \%$ sand, $16 \%$ silt, and $16 \%$ clay). Inoculums of banana $\mathrm{Fu}$ sarium wilt pathogen Fusarium oxysporum f. sp. cubense race 4 (FOC4) were prepared from potato dextrose broth and the soil was infested with $1 \%$ of the inoculums [33].

Banana explants were inoculated with endophytic bacteria by soaking in bacterial suspension $\left(10^{6} \mathrm{cfu} \mathrm{mL}^{-1}\right)$ for $2 \mathrm{~h}$. Explants soaked in the sterile LB medium were used as the controls. The inoculated and control plantlets were planted in pots with the soil. One plantlet was sown in each pot and five pots were set up for each treatment. The soil moisture was kept at $>95 \%$ of saturation. The banana plants were kept in a glasshouse at $25^{\circ} \mathrm{C}$ and day/night cycle of $16: 8 \mathrm{~h}$. The biocontrol effect was evaluated after 90 days of planting by measuring plant height, leaf area, pseudostem girth, and fresh and dry weights [35]. Disease index was evaluated based on 
the leave wilt index scale and vascular discoloration index [33]. The IAA and ethylene concentrations of banana leaves $(0.1 \mathrm{~g})$ were measured using the plant IAA and ethylene ELISA Kits (Kmsbiotech, Shanghai, China) according to the manufacturer's protocol, respectively.

\section{Statistical analysis}

OTUs using the QIIME software package at 97\% sequence identity and phylogenetic relationships among the different microbial taxa were displayed by KRONA $[36,37]$. Indices of Shannon, Chao1, Simpson, coverage, and ACE were calculated using Mothur to indicate the richness and diversity of the endophytic community in different samples [38].

All statistical analysis of data, including disease resistance, plant growth, ethylene concentrations, IAA concentrations, and enzyme activities, were performed using the SPSS statistical package (SPSS Inc., Chicago, USA). For the biocontrol experiments, analysis of variance (ANOVA) was conducted to compare the inoculation results among the different symbiotic bacteria. All statistical tests were subjected to ANOVA and the significance threshold was set up at $P<0.05$.

\section{Results}

The diversity and richness of bacterial and fungal species From the bacterial $16 \mathrm{~S} r D N A$ V3-V4 region and fungal ITS2 sequencing, 20,012 bacterial processed reads were obtained with an average length of $430 \mathrm{bp}$ and 113,780 fungal processed sequences with an average length of $338 \mathrm{bp}$ for the samples (Additional file 1: Table S1). These bacterial reads could be assigned to 61 to 2601 OTUs per sample at the $97 \%$ identity. The number of fungal OTUs at 97\% similarity ranged from 210 to 1915 in each sample. The bacterial and fungal species richness indices (i.e., Chao, ACE, Simpson, and Shannon indices) indicated that the roots contained more diverse bacteria and fungi than the shoot tips (Table 1). Although the tissue-cultured explants did not contact with exterior bacteria, the roots of explants contained more diverse bacteria than the pseudostems. The bacterial species richness indices in the shoot tips and roots increased with the growth of the banana plant. With the development of wilt disease, more diverse bacteria were detected in the shoot tips, whereas the roots of plants without wilting symptoms contained more diverse bacterial species than the roots of wilting plants. The roots of tissue-cultured explants contained more diverse endophytic fungi than the pseudostems. Contrary to endophytic bacteria, fungal species richness in the shoot tips and roots increased with the plant growth and wilt development.

Tissue cultures were initially from sucker-enclosed shoots tips after following extensive surface sterilization. The tissue-cultured explants contained the crucial microbial members transmitted from shoot tips. The comparison of microbial flora in explants with that in mature plants revealed the microbial taxa proliferating in planta during the different plant growth stages. A total of 38 shared bacterial OTUs were detected in pseudostems and roots of the tissue-cultured banana explants (i.e., Sstem and Sroot, respectively) (Fig. 1a). The proportion of shared bacterial OTUs in pseudostems was higher than that in roots $(51 \%$ vs. $26 \%)$. Compared with explants, the shared bacterial OTU number in mature plant roots and shoot tips (i.e., Broot and Btip) declined from 38 to 10 . Nine shared bacterial OTUs were detected in the explant pseudostems and healthy plant

Table 1 The alpha diversity indices of bacterial and fungal OTUs from samples of pseudostems and roots of explants (designated as Sstem and Sroot, respectively), shoot tips and roots of healthy banana plants in fields without wilting symptoms (designated as Btip and Broot, respectively), shoot tips and roots of wilting banana plants (designated as Wtip and Wroot, respectively), and shoot tips and roots of banana plants adjacent to the wilting plants but without wilting symptoms (designated as Htip and Hroot, respectively)

\begin{tabular}{|c|c|c|c|c|c|c|c|c|c|c|}
\hline \multirow[t]{2}{*}{ Sample } & \multicolumn{5}{|c|}{ Bacterial OTUs } & \multicolumn{5}{|l|}{ Fungal OTUs } \\
\hline & Chao 1* $^{*}$ & ACE & Shannon & Simpson & Coverage & Chao1 & ACE & Shannon & Simpson & Coverage \\
\hline Sstem & $147 \pm 3.1$ & $326 \pm 5.4$ & $2.85 \pm 0.07$ & $0.18 \pm 0.01$ & $0.85 \pm 0.03$ & $388 \pm 4.8$ & $596 \pm 11.0$ & $0.38 \pm 0.01$ & $0.86 \pm 0.01$ & $1.00 \pm 0.00$ \\
\hline Btip & $182 \pm 3.5$ & $662 \pm 11.1$ & $3.54 \pm 0.16$ & $0.05 \pm 0.00$ & $0.64 \pm 0.02$ & $633 \pm 5.7$ & $900 \pm 9.3$ & $0.73 \pm 0.03$ & $0.72 \pm 0.03$ & $1.00 \pm 0.00$ \\
\hline Htip & $250 \pm 3.3$ & $527 \pm 13.0$ & $3.62 \pm 0.18$ & $0.04 \pm 0.00$ & $0.60 \pm 0.03$ & $549 \pm 4.0$ & $811 \pm 13.1$ & $0.52 \pm 0.03$ & $0.80 \pm 0.01$ & $1.00 \pm 0.00$ \\
\hline Wtip & $432 \pm 4.5$ & $447 \pm 16.3$ & $3.75 \pm 0.15$ & $0.03 \pm 0.00$ & $0.34 \pm 0.01$ & $689 \pm 7.1$ & $1305 \pm 25.6$ & $0.58 \pm 0.01$ & $0.79 \pm 0.03$ & $1.00 \pm 0.00$ \\
\hline Sroot & $373 \pm 4.1$ & $621 \pm 11.5$ & $2.68 \pm 0.09$ & $0.24 \pm 0.01$ & $0.92 \pm 0.03$ & $950 \pm 10.6$ & $1421 \pm 22.4$ & $0.67 \pm 0.02$ & $0.81 \pm 0.02$ & $1.00 \pm 0.00$ \\
\hline Broot & $382 \pm 5.1$ & $531 \pm 13.2$ & $3.14 \pm 0.20$ & $0.12 \pm 0.00$ & $0.94 \pm 0.03$ & $2805 \pm 13.9$ & $3658 \pm 55.9$ & $2.65 \pm 0.07$ & $0.28 \pm 0.01$ & $0.99 \pm 0.01$ \\
\hline Hroot & $7443 \pm 17.5$ & $12576 \pm 53.1$ & $4.62 \pm 0.24$ & $0.14 \pm 0.00$ & $0.87 \pm 0.02$ & $2198 \pm 7.3$ & $3394 \pm 39.7$ & $2.00 \pm 0.03$ & $0.37 \pm 0.03$ & $0.99 \pm 0.01$ \\
\hline Wroot & $3723 \pm 13.7$ & $6671 \pm 23.1$ & $4.05 \pm 0.13$ & $0.19 \pm 0.00$ & $0.85 \pm 0.01$ & $4182 \pm 21.5$ & $6436 \pm 63.1$ & $2.99 \pm 0.06$ & $0.16 \pm 0.00$ & $0.98 \pm 0.02$ \\
\hline
\end{tabular}

*Both Chao1 and ACE described an estimate of the total number of phylotypes in a source environment, and Chao1 is particularly appropriate for data sets in which most phylotypes are relatively rare in the community, ACE is appropriate for data sets in which some phylotypes occur more frequently. Both Shannon and Simpson indexes comprehensively reflect the richness and evenness of community, while Shannon index is more sensitive to the richness of the community, and Simpson index is more sensitive to the evenness of the community. Coverage is a non-parametric estimator of the proportion of phylotypes in a library of infinite size that would be represented in a smaller library. Values are reported as mean \pm SD (standard deviation) $(n=5)$ 


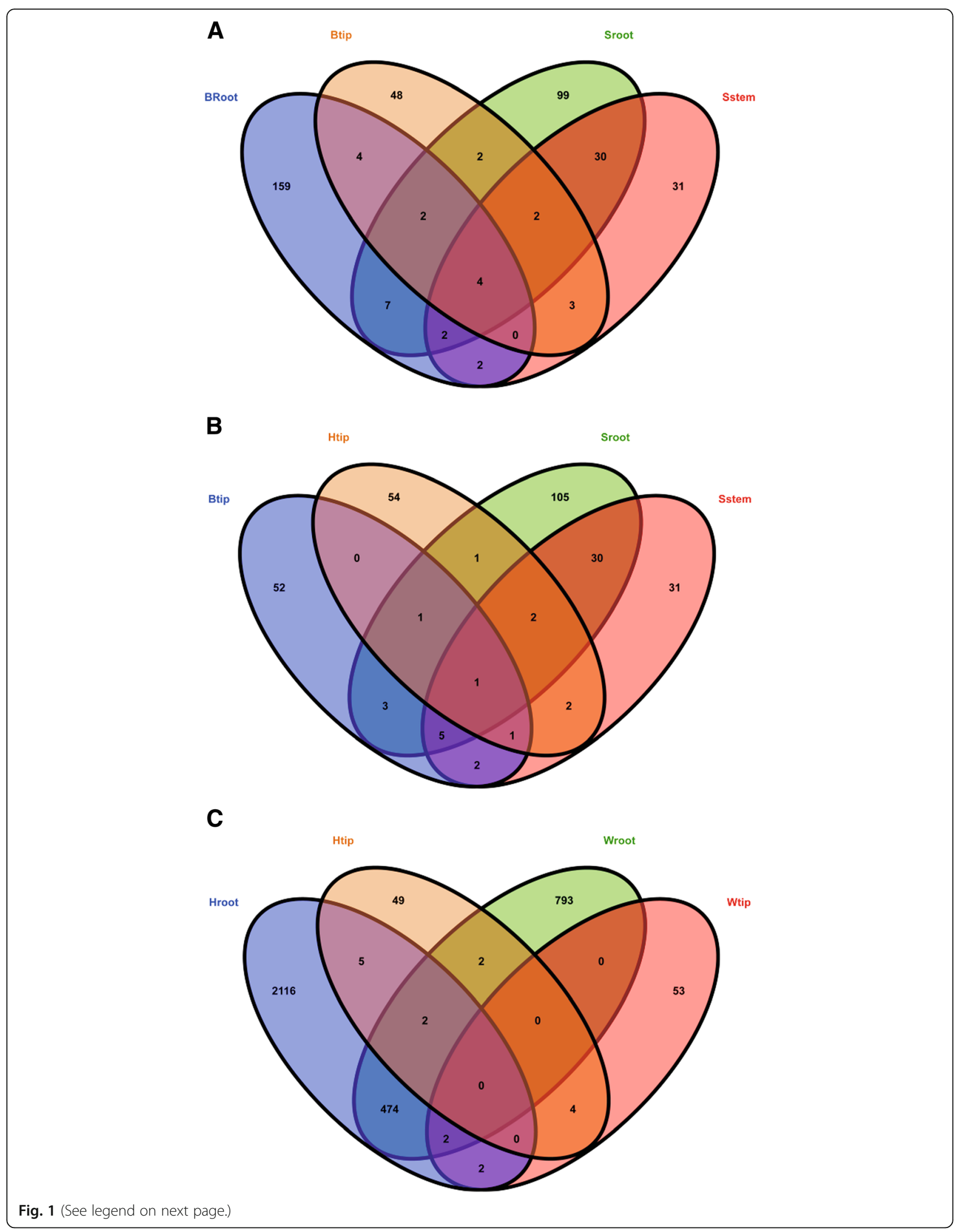


(See figure on previous page.)

Fig. 1 Venn diagrams of bacterial operational taxonomic units (OTUs) in samples of a pseudostems and roots of explants (designated as Sstem and Sroot, respectively) and shoot tips and roots of healthy banana plants in fields without wilting symptoms (Btip and Broot); $\mathbf{b}$ Btip, shoot tips of banana plants adjacent to the wilting plants but without wilting symptoms (Htip), Sroot, and Sstem; c shoot tips and roots of banana plants adjacent to the wilting plants but without wilting symptoms (Htip and Hroot), and shoot tips and roots of wilting banana plants (Wtip and Wroot). The Venn diagrams show the number of shared and unique OTUs in the samples. The different colored ovals represent different samples, and the intersections of the colored ovals indicate the coexisted bacterial OTUs in the samples

shoot tips (i.e., Sstem and Btip) and 15 OTUs shared in the explant roots and healthy plant roots (i.e., Sroot and Broot). The shared bacterial OTUs still proliferated from the explant roots and pseudostems to the plant shoot tips and roots during the explant development. Four bacterial OTUs belonged to the core bacterial taxa of banana plants because they were detected in the different plant organs (i.e., pseudostems, shoot tips, and roots) from the explants to mature plants with different wilting processes (Fig. 1a). During the development of Fusarium wilt, the number of shared bacterial OTUs in the shoot tips of plants without wilting symptoms (Htip) declined to 7. The shoot tips shared 3, 5, and 6 bacterial OTUs with Btip, Sroot, and Sstem, respectively. Only one OTU was shared within the four types of samples (i.e., Htip, Btip, Sroot, and Sstem) (Fig. 1b). After the appearance of wilting symptoms, the shared bacterial OTU number in shoot tips and roots of wilting plants (i.e., Wtip and Wroot) was reduced to 2 . Four OTUs still were detected in the plant shoot tips during the development of wilt symptoms (i.e., Wtip and Htip). The bacterial flora in roots varied slightly during the wilt development and 478 shared OTUs were detected in Wroot and Hroot (Fig. 1c). At the same time, 76 fungal OTUs were retained in the shoot tips (i.e., Wtip and Htip) and 414 OTUs in the roots (i.e., Wroot and Hroot) during plant wilting (Fig. 2a). Only one fungal OTU was shared in the shoot tips and roots during the wilting process, whereas the fungal OTUs were not affiliated with Fusarium. Consistent with bacteria, the banana explants contained 86 shared fungal OTUs in the roots and pseudostems (i.e., Sroot and Sstem) (Fig. 2b). The shared fungal OTU number in the healthy mature plant shoot tips and roots (i.e., Btip and Broot) declined to 3. During the sterile culture-tissue process, 48 fungal OTUs in the shoot tips (Btip) transmitted into the explant roots and pseudostems (i.e., Sroot and Sstem). Sixty-six fungal OTUs retained in banana shoot tips during the wilt pathogen infection (i.e., Btip and Htip), while the shared fungal OTU number in the shoot tips increased to 76 during the wilting symptom development (i.e., Wtip and Htip) (Fig. 2c). A total of 36 fungal OTUs in the explant pseudostems and roots (i.e., Sstem and Sroot) transmitted into the plant shoot tips during the processes of plant growth and infection by fungal pathogen (i.e., Btip and Htip) (Fig. 2). The banana plant also contained core mycobiome from explants to mature plants during fungal infection processes.

\section{Differences in fungal and bacterial community composition}

At the genus level, Caulobacter (15\%) and Paracoccus (2.9\%) were the abundant bacterial genera in the banana plants. Cladosporium (12\%) and Eurotium (4.2\%) were the predominant fungal genera in the plants. Erwinia, Salmonella, Klebsiella, Brenneria, Stenotrophomonas, and Lactococcus were the most detected bacterial genera in the banana explants (Sroot and Sstem) (Fig. 3). In the mature plants, bacterial taxa Halomonus, Erwinia, Klebsiella, and Citrobacter dominated in the shoot tips (Btip), and Amaricoccus, Paracoccus, Kocuria, and Micrococcus were most frequently detected in the plant roots (Broot) (Fig. 4). Infested by fungal pathogen, Acinetobacter, Bacillus, and Klebsiella became the dominant bacterial taxa in the shoot tips (Htip), and Caulobacter, Staphylococcus, and Comamonas dominated in the roots (Hroot) (Fig. 5). With the development of wilting, Acinetobacter and Klebsiella were still the dominant bacterial genera in the shoot tips (Wtip), and Caulobacter and Comamonas were the dominant bacterial genera in the roots (Wroot) (Fig. 6). Klebsiella was considered as the crucial bacterial taxa in banana plant because it was detected throughout the plant growth and wilting processes.

Cladosporium was the most frequently detected fungal genera in the healthy banana shoot tip (Btip). The fungal OTUs affiliated with Fusarium were not detected in the wilting plant roots, whereas Cladosporium, Penicillium, Aspergillus, Eurotium, and Cryptococcus were the dominant fungal genera in the roots (Wroot) (Fig. 7). Cladosporium, Penicillium, Aspergillus, and Cryptococcus might transmit from the explants because the fungal genera were more frequently detected in the explant roots (Sroot). During the infection process, Fusarium and Eurotium were detected in the roots of plants infested by the Fusarium pathogen (Hroot). With different relative abundance, Eichleriella was the crucial fungal taxa because it was detected in the pseudostems (shoot tips) and roots of explants and mature plants with different wilting stages (Fig. 8). 


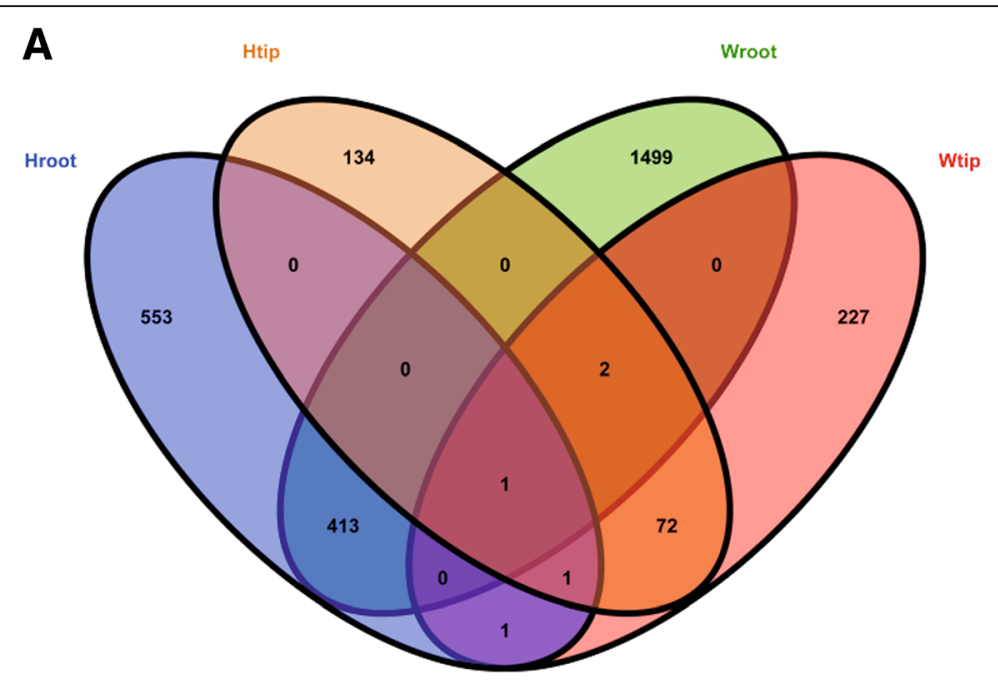

B
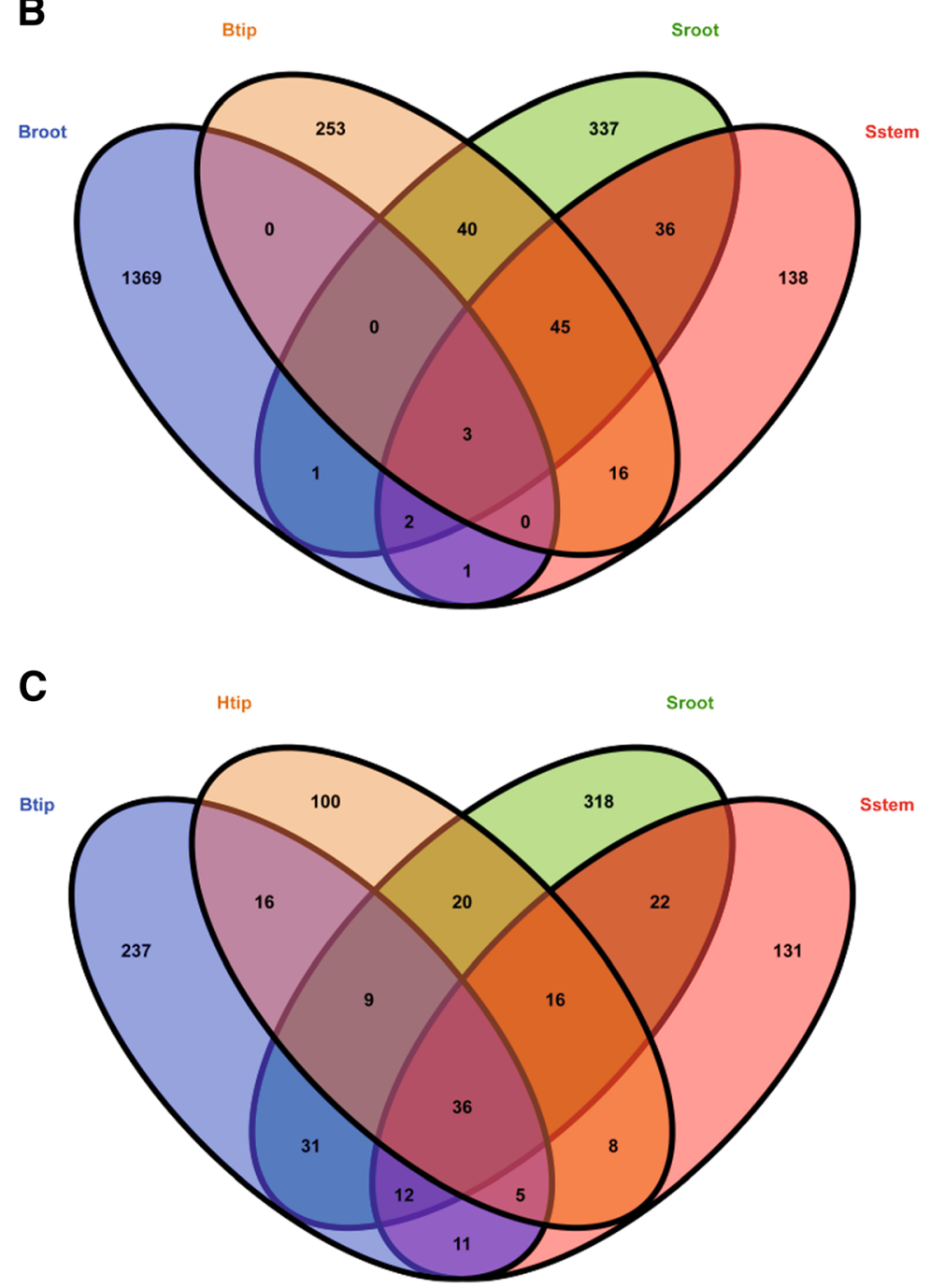

Fig. 2 (See legend on next page.) 
(See figure on previous page.)

Fig. 2 Venn diagrams of fungal operational taxonomic units (OTUs) in samples of a roots and shoot tips of banana plants adjacent to the wilting plants but without wilting symptoms (designated as Hroot and Htip, respectively) and shoot tips and roots of wilting banana plants (Wtip and Wroot); $\mathbf{b}$ pseudostems and roots of explants (Sstem and Sroot) and shoot tips and roots of healthy banana plants in fields without wilting symptoms (Btip and Broot); c Btip, Htip, Sroot, and Sstem. The Venn diagrams show the number of shared and unique OTUs in the samples. The different colored ovals represent different samples, and the intersections of the colored ovals indicate the coexisted bacterial OTUs in the samples

\section{Isolation of endophytic bacteria and transformed with surface display plasmids}

The keystone endophytic bacterial genera Klebsiella belonged to the Enterobacteriaceae. Colonies grown from the shoot tip pieces were picked out, transmitted, and purified on selective EMB agar. The purified bacterial isolates were identified as Kosakonia sp. S1 (S1), Enterobacter sp. E5 (E5), and Klebsiella sp. Kb (Kb) by $16 \mathrm{~S}$ $r R N A$ gene sequencing analysis. The constructed surface display plasmids with ACC deaminase genes were transferred into E5, S1, and $\mathrm{Kb}$ cells with electroporation. The engineered strains of $\mathrm{E} 5, \mathrm{~S} 1$, and $\mathrm{Kb}$ with plasmids were designated as E5P, S1P, and KbP, respectively. Klebsiella $\mathrm{sp}$. $\mathrm{Kb}$ produced $>150 \mathrm{mg} \mathrm{L}^{-1}$ IAA, while E5 and S1 produced $<30 \mathrm{mg} \mathrm{L}^{-1}$ IAA in the media with and without tryptophan (Trp) addition. Plate confronting tests indicated that the strains of E5, E5P, S1, S1P, Kb, and $\mathrm{KbP}$ did not show any antagonism to the wilt

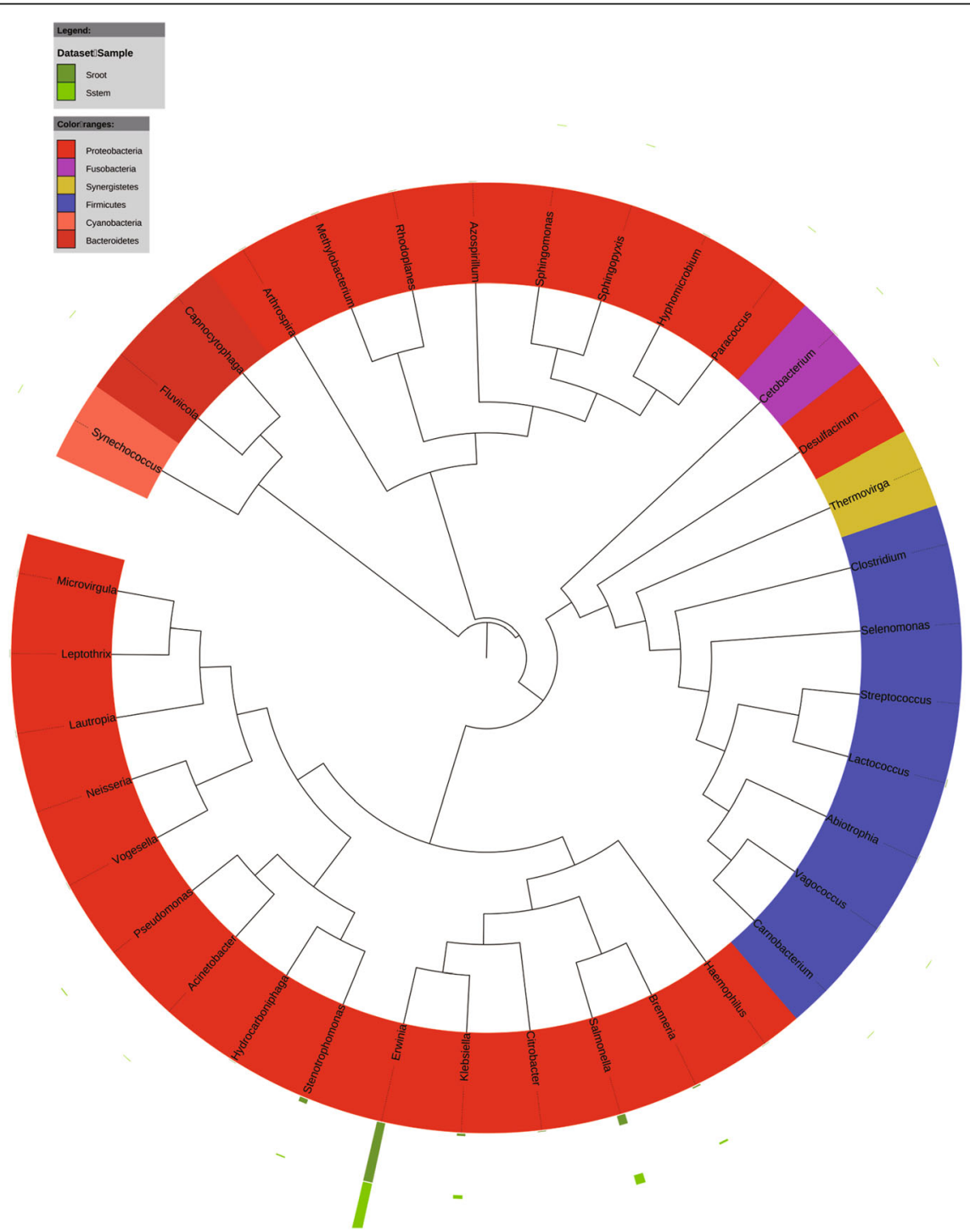

Fig. 3 Phylogenetic analysis of bacterial operational taxonomic units (OTUs) in pseudostems and roots of explants (designated as Sroot and Sstem, respectively) 


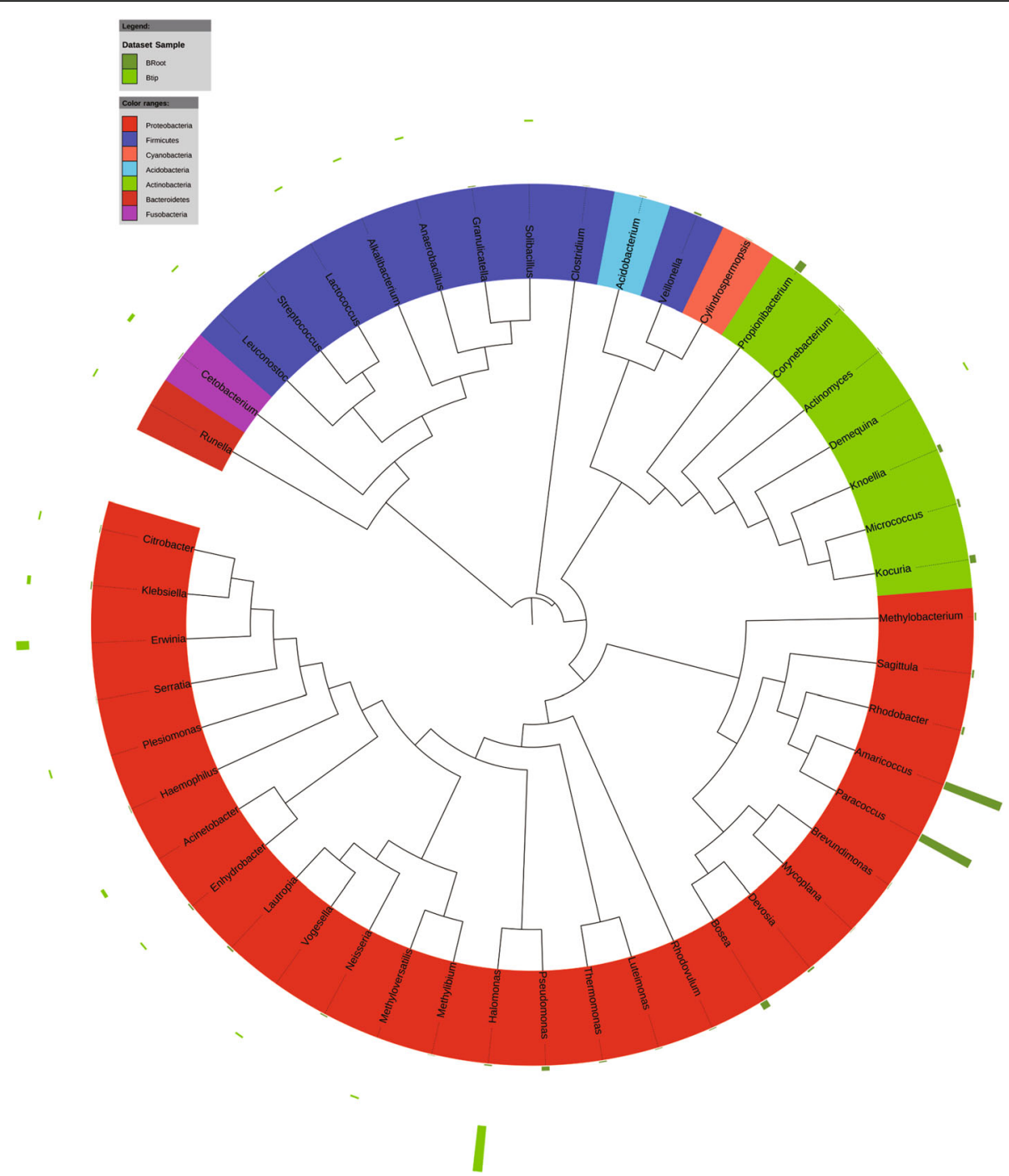

Fig. 4 Phylogenetic analysis of bacterial operational taxonomic units (OTUs) in shoot tips and roots of healthy banana plants (designated as Broot and Btip, respectively)

pathogen FOC4 on the banana pseudostem extract medium. The growth of the six strains was not influenced by the addition of $100 \mu \mathrm{g} \mathrm{mL}^{-1}$ fusaric acid in vitro. These strains could tolerate the fusaric acid concentration of $400 \mu \mathrm{g} \mathrm{mL}^{-1}$ in the banana pseudostem extract medium. The bacterial strains could survive in banana plant tissues after the wilting symptoms appeared.

Without bacterial cells permeabilized with toluene, the ACC deaminase activities of the three wild bacterial isolates (i.e., E5, S1, and $\mathrm{Kb}$ ) were similar, and the differences among the concentrations of $\alpha$-ketobutyrate released from ACC were not significant $(P>0.05)$ (Table 2). The ACC deaminase activities of the isolates did not increase after the cells were permeabilized by toluene. The ACC deaminase gene transformed into
Klebsiella sp. Kb did not express, as shown by the insignificant difference of ACC deaminase activities between $\mathrm{Kb}$ and $\mathrm{KbP}$. The ACC deaminase activities of E5P and S1P permeabilized with toluene were 1.4 times higher than those of the corresponding strains without the toluene treatment. The most of ACC deaminase was expressed in cell envelopment interiors of E5P and S1P, and about $40 \%$ of the ACC deaminase was displayed on the cell walls of the strains.

\section{Effects of bacterial inoculation on growth and disease resistance of banana}

After the plantlets were grown in the FOC4 infested soil for 90 days, the growth parameters (i.e., plant height, pseudostem girth, leaf area, and fresh and dry weights) of plants inoculated with the wild and engineered strains 


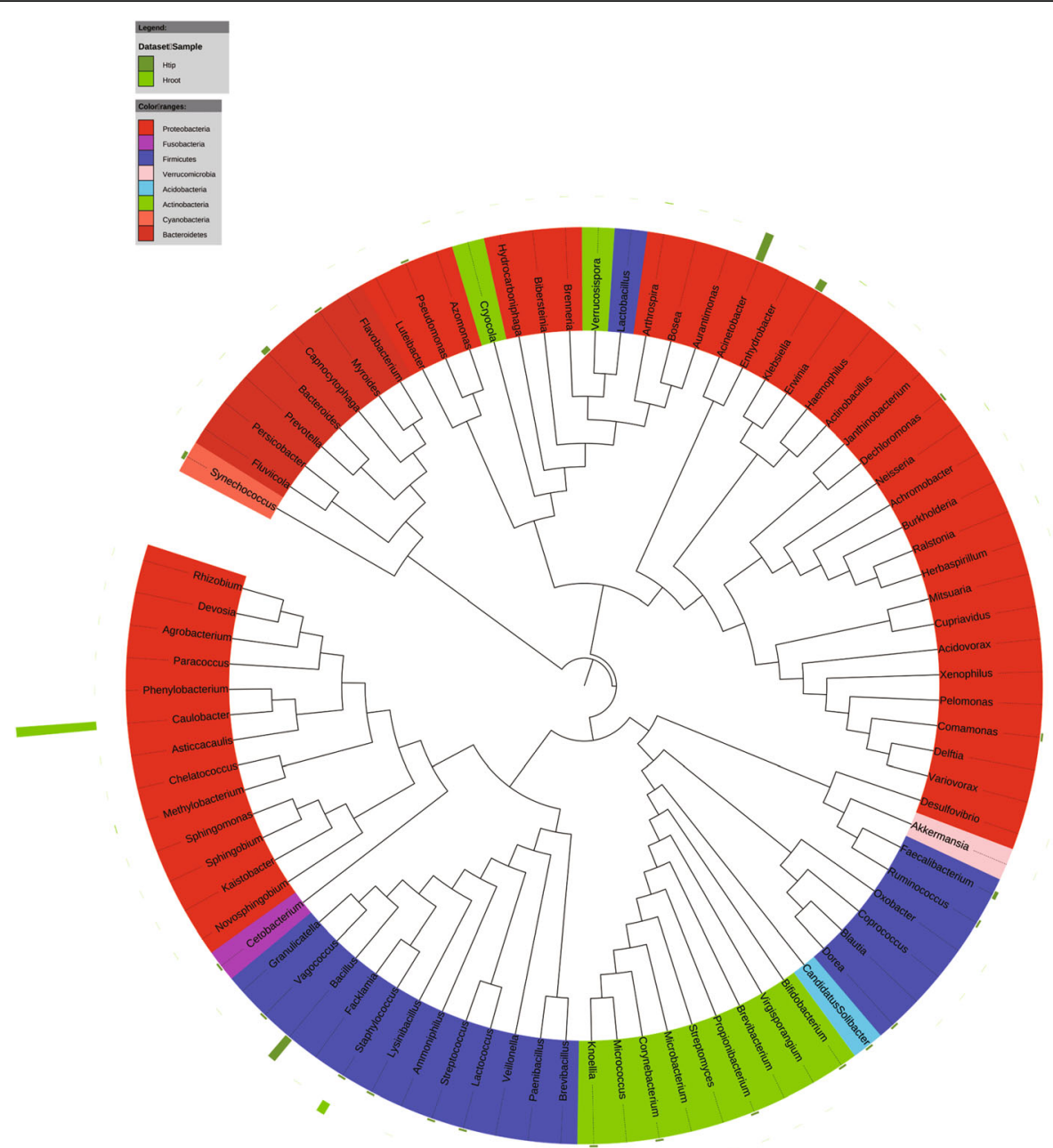

Fig. 5 Phylogenetic analysis of bacterial operational taxonomic units (OTUs) in shoot tips and roots of banana plants adjacent to the wilting plants but without wilting symptoms (designated as Hroot and Htip, respectively)

were compared. The growth parameters of plants inoculated with the six strains were improved compared with the controls without inoculation (Additional file 1: Figure $\mathrm{S} 2 \mathrm{~A})$. The inoculation with $\mathrm{Kb}$ improved stem girth, leaf area, and fresh and dry weights of the plants and reduced the Fusarium wilt disease index by $10 \%$ (Table 3). The inoculation with E5 and S1 promoted the plant growth and reduced the Fusarium wilt disease index by about $25 \%$ and $40 \%$, respectively. The inoculation with engineered strains E5P and S1P further improved the growth of banana plants and reduced the wilt disease index by $63 \%$ and $57 \%$, respectively (Additional file 1: Figure S2B). The ACC deaminase of bacterial strains might be involved in the growth promoting and wilt resistance of banana plants (Table 3). The ACC deaminase on cell walls of endophytic strains could degrade ethylene synthesis precursor ACC and reduce ethylene levels in planta. At the same time, the plant IAA level increased. Inoculation with $\mathrm{KbP}$ without ACC deaminase activity did not reduce the ethylene level and not increase the plant IAA level compared with $\mathrm{Kb}$ (Table 3).

\section{Discussion}

Despite decades of research, few effective methods are available to manage the banana Fusarium wilt disease. Resistance cultivar breeding is the best management method in affected areas. However, such bio-resources are often scarce, nonproductive, and commercially unacceptable [3]. It is difficult to create resistant cultivars using genetic transformation via the conventional breeding. Biocontrol using indigenous and disease-suppressive microorganisms can provide potential perspectives for sustainable plant protection [1]. Some antagonistic bacterial and fungal isolates from root endosphere and rhizosphere have been tested to control Fusarium wilt $[1,33]$. In this study, the endophytic bacterial and fungal 


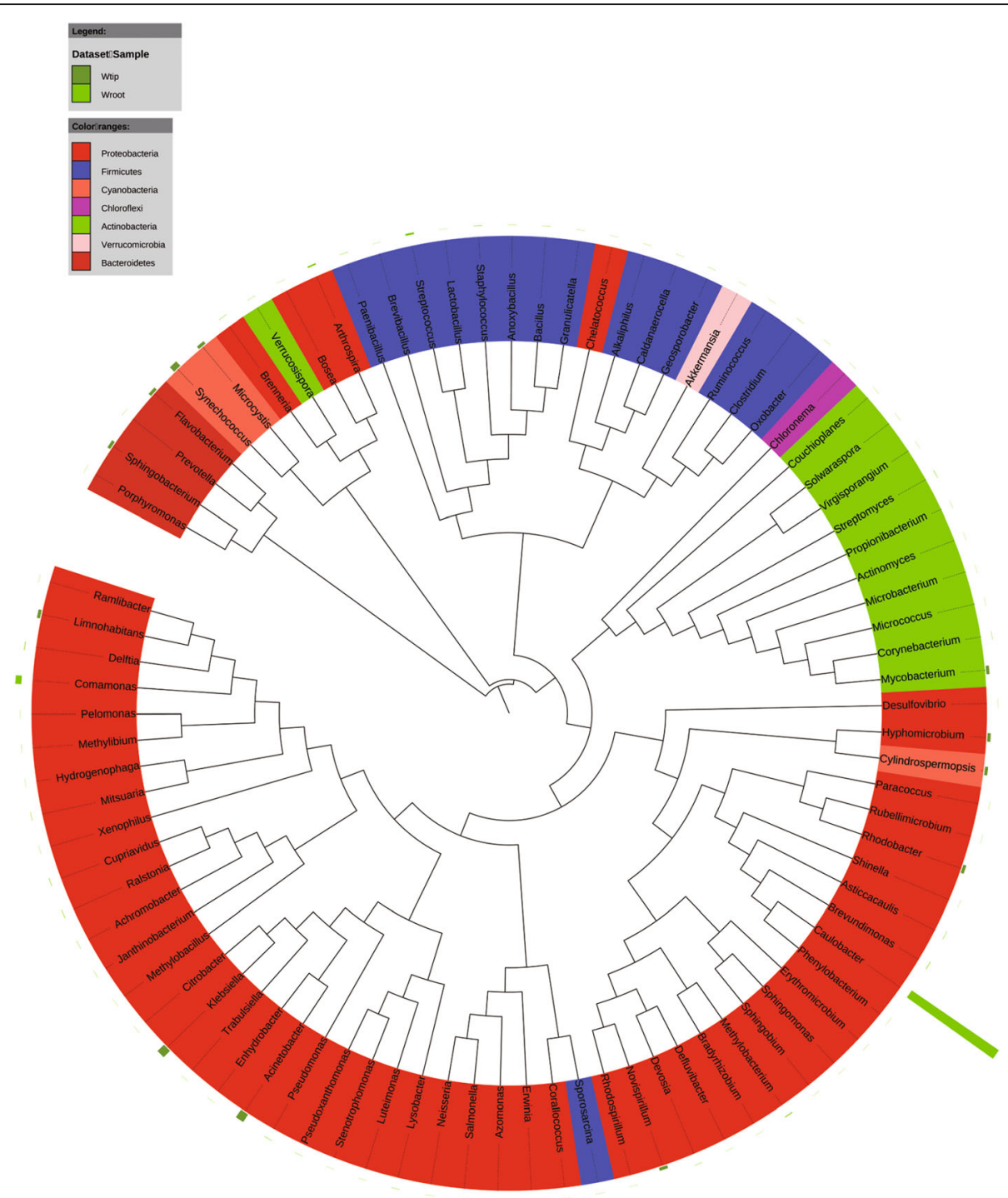

Fig. 6 Phylogenetic analysis of bacterial operational taxonomic units (OTUs) in shoot tips and roots of wilting banana plants (designated as Wroot and Wtip, respectively)

community variations were compared during banana plant growth, fungal infection, and wilting process. The fungal species richness (i.e., OTUs) in shoot tips increased with the banana plant growth and wilting development. The relative abundance of fungal OTUs affiliated with Fusarium did not increase during the wilting process. The wilting symptoms of banana plants were not correlated with the overgrowth of banana wilt pathogen in plant tissue but might be related to the ethylene level induced by pathogenic fungi [17, 18]. Therefore, the antagonistic activities of biocontrol agents towards Fusarium pathogen is not necessary to control banana Fusarium wilt and effective fungicides are not available to control the wilt disease nowadays [3]. The three Enterobacteriaceae isolates without antagonism to wilt pathogen promoted the growth and disease resistance of banana plants in our study. The antagonism to pathogenic fungi in vitro was not essential in selection for biocontrol agents. However, the tolerance to fusaric acid was essential because that fusaric acid played a critical role in accelerating the development of Fusarium wilt and inhibiting the growth of biocontrol strain by acting as a phytotoxin $[34,39]$.

Most studies on plant microbiome focused on rhizosphere bacteriome [6]. The endosphere bacteriome in banana shoot tips and plant mycobiome during plant growth and wilting development should be further studied. The seated shoot tips inside layers of leaf sheaths are usually used as starting material for micropropagated banana explants. The tissue-cultured explants may contain a genotype-specific core banana microbiome transmitted from shoot tips of last generation [40]. Since the 


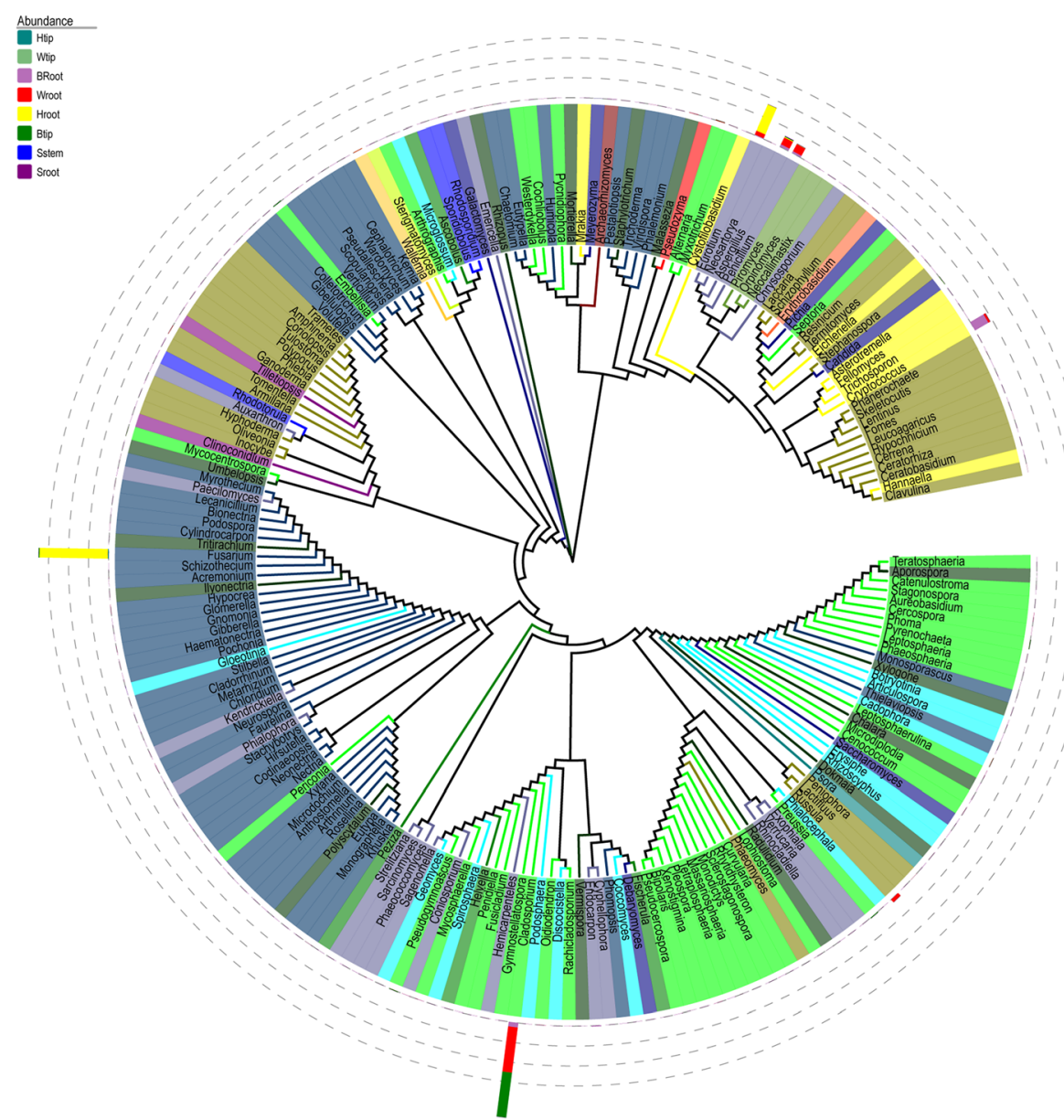

Fig. 7 Phylogenetic analysis of fungal operational taxonomic units (OTUs) in samples of pseudostems and roots of explants (designated as Sstem and Sroot, respectively), shoot tips and roots of healthy banana plants in fields without wilting symptoms (Btip and Broot), shoot tips and roots of wilting banana plants (Wtip and Wroot), and shoot tips and roots of banana plants adjacent to the wilting plants but without wilting symptoms (Htip and Hroot)

explants grew under an aseptic condition, the roots differentiated from embryogenic suspension cultures of banana might not contact with exterior microbes. The bacterial and fungal florae in the explant pseudostem were similar to those in the explant roots. During plant growth, the banana bacterial and fungal florae might transmit between shoot tips and roots. Therefore, the core bacteriome and mycobiome could be detected in mature plant root interiors.

Plant core microorganisms establish consistently in plants and are not influenced by different spaces, time, and plant organs [16]. Caulobacter and Paracoccus were the most abundant bacterial genera in some banana samples. However, they were not considered as the crucial core bacterial endophytes because they were not detected in all the samples during the plant growth and wilt development processes. With lower relative abundance, Enterobacteriaceae endophytes of Enterobacter spp. and Klebsiella spp. were considered as the core bacterial taxa in banana because they were detected in roots and pseudostems (shoot tips) of banana explants and plants in the different wilting processes. Endophytic Enterobacteriaceae including Klebsiella genera have been detected from different tissues of banana with different methods [1, 40-45]. Enterobacteriaceae (Enterobacter spp. and Klebsiella spp.) may proliferate in plant tissues and transmit from generation to generation in banana growth and proliferation. Klebsiella and Enterobacter are more beneficial to banana plants than other microbial taxa [46]. Therefore, Enterobacteriaceae bacteria were considered as the keystone bacteriome in banana plants, whereas the keystone bacteria may not be dominant in numbers [47].

Although the core bacterial and fungal communities in banana plants have been elucidated, there is still a lack of knowledge about the relationships between endophytes and host plants [48]. In plants, IAA produced by endophytic bacteria serves as signals that intense plant-microbe 


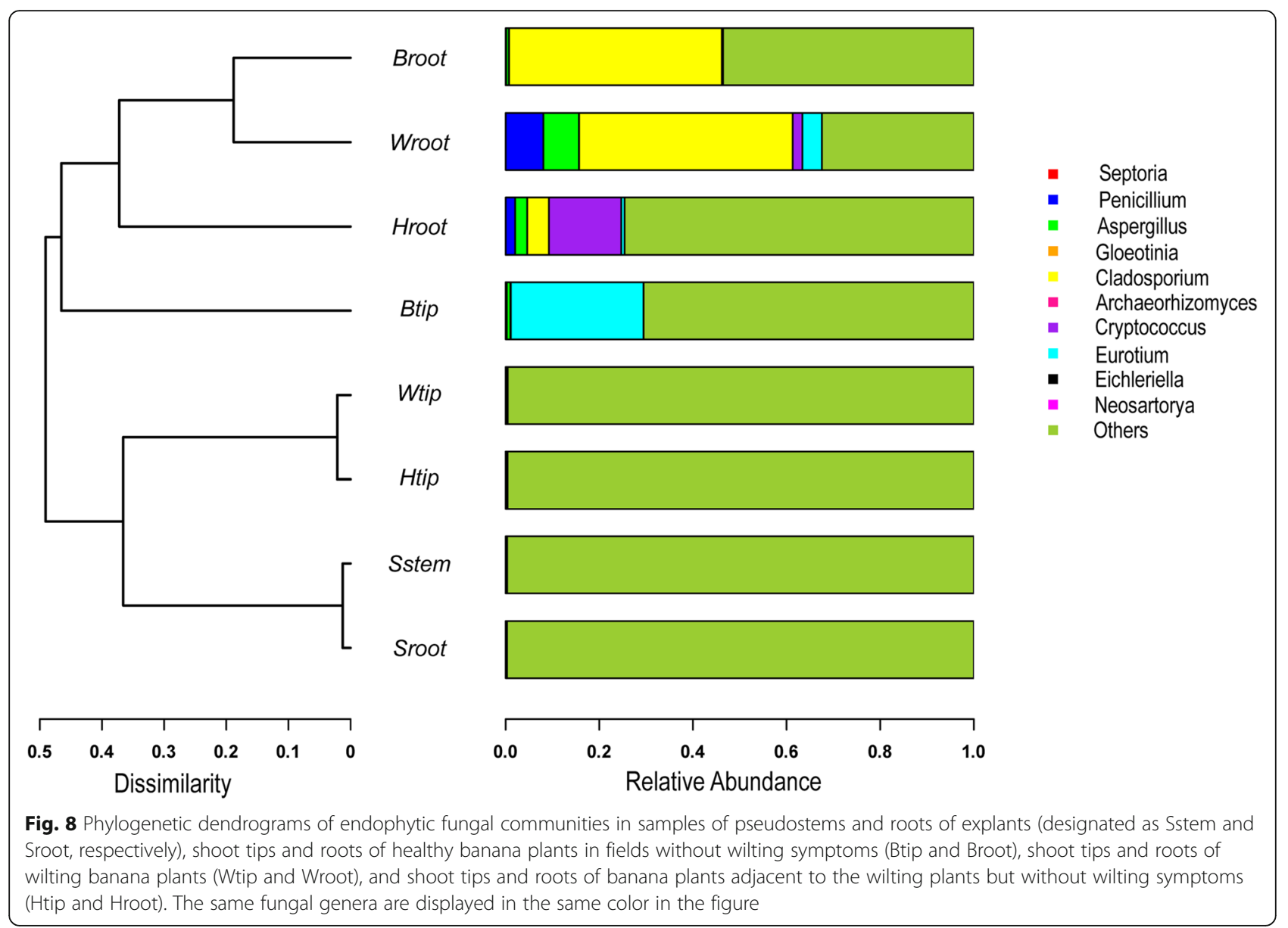

interplay [15]. As shown in Tables 2 and 3, $\mathrm{Kb}$ produced fivefolds more IAA than E5 in the medium. However, the IAA contents of plantlets inoculated with $\mathrm{Kb}$ and $\mathrm{KbP}$ were lower than that with E5 (Table 2). The inoculation of IAA-producing $\mathrm{Kb}$ and $\mathrm{KbP}$ into plantlets did not increase IAA contents in planta. The engineered strain KbP without ACC deaminase activity did not reduce the ethylene level and not increase IAA contents in planta (Table 3). Therefore, the IAA increase in planta was correlated with bacterial ACC deaminase activities but not correlated with bacterial IAA production in the medium [49]. The increase in IAA contents in planta might be produced by host plants. The Salkowski reagents are specific for indoleacetamide, indolepyruvic acid, and IAA rather than for IAA

Table 2 The deaminase activity of 1-aminocyclopropane-1-carboxylate (ACC) and the indole-3-acetic acid (IAA) concentrations in different strains of Kosakonia sp. S1 (S1), Enterobacter sp. E5 (E5), Klebsiella sp. Kb (Kb), and the engineered strains of E5, S1, and Kb (designated as E5P, S1P, and KbP, respectively) by expressing deaminase on the bacterial cells

\begin{tabular}{|c|c|c|c|c|}
\hline & \multicolumn{2}{|c|}{ Concentration of a-ketobutyrate (mM) } & \multicolumn{2}{|c|}{ Concentration of IAA $\left(\mathrm{mg} \mathrm{L}^{-1}\right)$ by Salkowski reagent } \\
\hline & With toluene & Without toluene & Without Trp & With Trp \\
\hline Control & $0.00 \pm 0.00 b$ & $0.01 \pm 0.00 \mathrm{~b}$ & $0.33 \pm 0.04 c$ & $0.41 \pm .005 c$ \\
\hline S1 & $0.06 \pm 0.01 b$ & $0.03 \pm 0.01 b$ & $27.1 \pm 1.33 b$ & $39.5 \pm 3.46 b$ \\
\hline S1P & $4.94 \pm 0.35 a$ & $2.05 \pm 0.13 a$ & ND & ND \\
\hline E5 & $0.06 \pm 0.01 b$ & $0.05 \pm 0.01 b$ & $22.6 \pm 2.10 b$ & $45.1 \pm 2.73 b$ \\
\hline E5P & $4.82 \pm 0.17 a$ & $1.96 \pm 0.35 a$ & ND & ND \\
\hline $\mathrm{Kb}$ & $0.04 \pm 0.01 b$ & $0.03 \pm 0.01 b$ & $155 \pm 11.2 \mathrm{a}$ & $161 \pm 12.9 \mathrm{a}$ \\
\hline $\mathrm{KbP}$ & $0.11 \pm 0.01 b$ & $0.08 \pm 0.01 b$ & ND & ND \\
\hline
\end{tabular}

The different letters within columns indicate that the values are significantly different at $P<0.05$. Values are reported as mean \pm SD (standard deviation) ( $n=5$ ) ND not determined 
Table 3 Banana growth factors, ethylene concentrations, and indole-3-acetic acid (IAA) concentrations of banana of the control treatments (CK) and treatments with artificial inoculation of endophytes Kosakonia sp. S1 (S1), Enterobacter sp. E5 (E5), Klebsiella sp. $\mathrm{Kb}(\mathrm{Kb})$, and the engineered strains of E5, S1, and Kb (designated as E5P, S1P, and KbP, respectively) by expressing deaminase on the bacterial cells

\begin{tabular}{|c|c|c|c|c|c|c|c|c|}
\hline Treatment & $\begin{array}{l}\text { Plant height } \\
(\mathrm{cm})\end{array}$ & $\begin{array}{l}\text { Pseudostem } \\
\text { girth }(\mathrm{cm})\end{array}$ & Leaf area $\left(\mathrm{cm}^{2)}\right.$ & Fresh weight (g) & Dry weight (g) & Disease index & $\begin{array}{l}\text { Concentration of } \\
\text { ethylene }\left(\mathrm{nmol} \mathrm{L}{ }^{-1}\right)\end{array}$ & $\begin{array}{l}\text { Concentration of } \\
\text { IAA }\left(n m o \mid L^{-1}\right)\end{array}$ \\
\hline CK & $16.03 \pm 0.50 \mathrm{e}$ & $4.07 \pm 0.60 d$ & $91.53 \pm 3.23 d$ & $41.73 \pm 6.77 d$ & $13.50 \pm 3.54 c$ & $62.67 \pm 8.52 \mathrm{a}$ & $89.51 \pm 2.48 a$ & $60.09 \pm 2.05 e$ \\
\hline S1 & $18.97 \pm 0.60 c$ & $7.10 \pm 0.30 c$ & $134.6 \pm 10.57 b c$ & $59.93 \pm 1.00 c$ & $22.17 \pm 0.64 b$ & $33.67 \pm 5.08 \mathrm{e}$ & $71.90 \pm 3.13 \mathrm{~cd}$ & $68.01 \pm 2.04 \mathrm{~cd}$ \\
\hline S1P & $21.17 \pm 0.95 b$ & $9.30 \pm 0.56 a$ & $208.0 \pm 5.55 a$ & $102.6 \pm 12.17 a$ & $37.40 \pm 5.70 a$ & $26.67 \pm 4.53 f$ & $63.70 \pm 3.73 \mathrm{ef}$ & $76.10 \pm 2.75 b$ \\
\hline E5 & $17.77 \pm 0.38 \mathrm{~cd}$ & $6.60 \pm 0.36 c$ & $122.9 \pm 12.84 c$ & $58.07 \pm 6.56 c$ & $22.03 \pm 3.42 b$ & $47.00 \pm 6.00 d$ & $69.51 \pm 3.13 \mathrm{de}$ & $70.19 \pm 1.82 c$ \\
\hline E5P & $23.63 \pm 1.25 a$ & $8.43 \pm 0.15 b$ & $207.3 \pm 6.99 a$ & $111.2 \pm 12.86 a$ & $41.53 \pm 5.52 \mathrm{a}$ & $23.33 \pm 4.58 f$ & $57.94 \pm 2.90 f$ & $80.57 \pm 1.40 a$ \\
\hline $\mathrm{Kb}$ & $16.67 \pm 0.60 \mathrm{de}$ & $7.03 \pm 0.60 c$ & $138.8 \pm 6.69 \mathrm{~b}$ & $74.40 \pm 5.22 b$ & $27.50 \pm 0.75 b$ & $56.00 \pm 7.00 \mathrm{~b}$ & $82.92 \pm 5.77 b$ & $65.99 \pm 1.34 d$ \\
\hline $\mathrm{KbP}$ & $16.83 \pm 1.47 \mathrm{de}$ & $7.43 \pm 0.35 c$ & $144.8 \pm 10.61 b$ & $74.77 \pm 3.25 b$ & $27.70 \pm 1.40 b$ & $51.67 \pm 6.53 c$ & $77.94 \pm 4.33 b c$ & $66.96 \pm 1.82 \mathrm{~cd}$ \\
\hline
\end{tabular}

The different letters within columns indicate that the values are significantly different at $P<0.05$. Values are reported as mean \pm SD (standard deviation) ( $n=5$ )

alone [32]. Thus, the Salkowski reagents are not suitable for screening plant beneficial bacteria in vitro.

It remains difficult to correlate microbial OTUs with physiology nowadays [16]. In this study, the isolated Klebsiella and Enterobacter strains did not show any ACC deaminase activity in vitro. The Klebsiella and Enterobacter strains were further engineered by expressing ACC deaminase activity on the bacterial cells because the ACC produced by plants can contact with ACC deaminase on the endophytic bacterial cells in planta. Compared with the engineered Klebsiella strains without ACC deaminase activity, the engineered Enterobacter strains with ACC deaminase activity could reduce the plant ethylene levels. The engineered Enterobacter strains without IAA production showed the potentials to promote plant growth and wilt resistance.

\section{Conclusions}

In this study, the variation of endosphere bacteriome and mycobiome of the banana plant during plant growth and wilting development suggested that the banana plant contained core bacterial and fungal taxa despite of plant physiological variation. The outgrowth of wilt pathogen did not occur during wilt development. The wilting symptom development was related with ethylene levels induced by pathogenic fungi. Although the keystone species Enterobacter sp. E5 did not show any activity against pathogenic fungi FOC4 in vitro, engineered Enterobacter sp. E5 with ACC deaminase activity on cells could promote banana plant growth and increase resistance to banana Fusarium wilt. Our results suggested that regulation of ethylene levels of banana plantlets by engineering plant core bacterial function may be of great interests to breeding banana resistant cultivars to Fusarium wilt. The novel strategies of engineering the interactions between endosphere microbiome with host plants provided valuable methods to build next-generation suitable agriculture.

\section{Additional files}

Additional file 1: Figure S1, S2, and Table S1 Supplementary Table and Figures. (DOC $226 \mathrm{~kb}$ )

\section{Funding}

This study was supported by grants from the National Natural Science Foundation of China (No. 41471181), Natural Science Foundation of Guangdong Province (No. 2018A0303130071).

\section{Availability of data and materials}

The Illumina MiSeq sequences for this study have been deposited in GenBank under the accession numbers of SRP055897 (16S) and SRP061527 (ITS). The 165 rDNA data has been deposited in NCBI GenBank under the accession numbers of KY800390, KY8003901, and KY8003902.

\section{Authors' contributions}

$Y L, A Z$, and $L C$ conceived the study. $Y L$ and $A Z$ designed and performed the experiments. YL wrote the first draft of the manuscript. LC, HT, and RZ revised the manuscript. All authors edited the manuscript and approved the final version.

Ethics approval and consent to participate

All procedures performed in studies involving human participants were in accordance with the ethical standards of the institutional and/or national research committee. All protocols were approved by the Ethical Review Panel of Sun Yat-sen University (SYSU).

Consent for publication

Not applicable.

Competing interests

The authors declare that they have no competing interests.

\section{Publisher's Note}

Springer Nature remains neutral with regard to jurisdictional claims in published maps and institutional affiliations.

Received: 6 December 2018 Accepted: 5 May 2019

Published online: 15 May 2019

\section{References}

1. Rossmann B, Müller H, Smalla K, Mpiira S, Tumuhairwe JB, Staver C. Banana-associated microbial communities in Uganda are highly diverse but dominated by Enterobacteriaceae. Appl Environ Microbiol. 2012; 78(14):4933-41. 
2. Paparu P, Dubois T, Gold CS, Niere B, Adipala E, Coyne D. Screenhouse and field persistence of nonpathogenic endophytic Fusarium oxysporum in Musa tissue culture plants. Microb Ecol. 2008;55(3):561-8.

3. Ploetz RC. Management of Fusarium wilt of banana: a review with special reference to tropical race 4. Crop Prot. 2015;73:7-15.

4. Thomas P, Soly TA. Endophytic bacteria associated with growing shoot tips of banana (Musa sp.) cv. Grand Naine and the affinity of endophytes to the host. Microb Ecol. 2009;58(4):952-64.

5. van der Heijden MGA, Schlaeppi K. Root surface as a frontier for plant microbiome research. Proc Natl Acad Sci USA. 2015;112(8):2299-300.

6. Turner TR, James EK, Poole PS. The plant microbiome. Genome Biol. 2013; 14(6):209.

7. Kwak MJ, Kong HG, Choi K, Kwon SK, Song JY, Lee J, et al. Rhizosphere microbiome structure alters to enable wilt resistance in tomato. Nat Biotechnol. 2018:36:1100-9.

8. Harish S, Kavino M, Kumar N, Saravanakumar D, Soorianathasundaram K, Samiyappan R. Biohardening with plant growth promoting rhizosphere and endophytic bacteria induces systemic resistance against banana bunchy top virus. Appl Soil Ecol. 2008;39(2):187-200.

9. Kavino M, Harish S, Kumar N, Saravanakumar D, Damodaran T, Soorianathasundaram K, et al. Rhizosphere and endophytic bacteria for induction of systemic resistance of banana plantlets against bunchy top virus. Soil Biol Biochem. 2007:39(5):1087-98.

10. Sikora RA, Pocasangre L, Felde A, Niere B, Vu TT, Dababat AA. Mutualistic endophytic fungi and in-planta suppressiveness to plant parasitic nematodes. Biol Control. 2008;46:15-23.

11. Xia X, Lie TK, Qian X, Zheng Z, Huang Y, Shen Y. Species diversity, distribution, and genetic structure of endophytic and epiphytic Trichoderma associated with banana roots. Microb Ecol. 2011;61(3):619-25.

12. Orozco-Mosqueda MC, Rocha-Granados MC, Glick BR, Santoyo G. Microbiome engineering to improve biocontrol and plant growthpromoting mechanisms. Microbiol Res. 2018;208:25-31.

13. Wang Y, Xia Q, Gu W, Sun J, Zhang H, Lu H, et al. Isolation of a strong promoter fragment from endophytic Enterobacter cloacae and verification of its promoter activity when its host strain colonizes banana plants. Appl Microbiol Biotechnol. 2012;93(4):1585-99.

14. Truyens S, Weyens N, Cuypers A, Vangronsveld J. Bacterial seed endophytes: genera, vertical transmission and interaction with plants. Environ Microbiol Rep. 2014. https://doi.org/10.1111/1758-2229.12181

15. Berg G, Rybakova D, Grube M, Koberl M. The plant microbiome explored: implications for experimental botany. J Exp Bot. 2016;67:995-1002.

16. Vorholt JA, Vogel C, Carlstrom Cl, Muller DB. Establishing causality: opportunities of synthetic communities for plant microbiome research. Cell Host Microbe. 2017;22(8):142-55.

17. VanderMolen GE, Labavitch JM, Strand LL, DeVay JE. Pathogen-induced vascular gels: ethylene as a host intermediate. Physiol Planta. 1983;59(4): 573-80

18. Jennings JC, Apel-Birkhold PC, Bailey BA, Anderson JD. Induction of ethylene biosynthesis and necrosis in weed leaves by Fusarium oxysporum protein. Weed Sci. 2000;48(1):7-14.

19. Glick BR. Modulation of plant ethylene levels by the bacterial enzyme ACC deaminase. FEMS Microbiol Let. 2005;251(1):1-7.

20. Wang W, Zhai Y, Cao L, Tan H, Zhang R. Endophytic bacterial and funga microbiota in sprouts, roots and stems of rice (Oryza sativa L.). Microbiol Res. 2016;188-189:1-8.

21. Degnan $\mathrm{PH}$, Ochman $\mathrm{H}$. Illumina-based analysis of microbial community diversity. ISME J. 2012;6(1):183-94.

22. Caporaso JG, Lauber CL, Walters WA, Berg-Lyons D, Huntley J, Fierer N, et al. Ultra-high-throughput microbial community analysis on the Illumina HiSeq and MiSeq platforms. ISME J. 2012;6(8):1621-4.

23. Magoč T, Salzberg SL. FLASH: fast length adjustment of short reads to improve genome assemblies. Bioinformatics. 2011;27(21):2957-63.

24. Bokulich NA, Subramanian S, Faith JJ, Gevers D, Gordon Jl, Knight R, et al. Quality-filtering vastly improves diversity estimates from illumine amplicon sequencing. Nat Methods. 2013;10(1):57-9.

25. Edgar RC, Haas BJ, Clemente JC, Quince C, Knight R. UCHIME improves sensitivity and speed of chimera detection. Bioinformatics. 2011;27(16): 2194-200.

26. Haas BJ, Gevers D, Earl AM, Feldgarden M, Ward DV, Giannoukos G, et al. Chimeric 16S rRNA sequence formation and detection in Sanger and 454pyrosequenced PCR amplicons. Genome Res. 2011;21(3):494-504.
27. Edgar RC. UPARSE: highly accurate OTU sequences from microbial amplicon reads. Nat methods. 2013;10(10):996-8.

28. Wang Q, Garrity GM, Tiedje JM, Cole JR. Naïve Bayesian classifier for rapid assignment of rRNA sequences into the new bacterial taxonomy. Appl Environ Microbiol. 2007;73(16):5261-7.

29. Qiu Z, Tan H, Zhou S, Cao L. Enhanced phytoremediation of toxic metals by inoculating endophytic Enterobacter sp. CBSB1 expressing bifunctional glutathione synthase. J Hazard Mater. 2014;267:17-20.

30. Liu Y, Cao L, Tan H, Zhang R. Surface display of ACC deaminase on endophytic Enterobacteriaceae strains to increase saline resistance of host rice sprouts by regulating plant ethylene synthesis. Microb Cell Fact. 2017; 16(1):214

31. Siddikee MA, Glick BR, Chauhan PS, Yim WJ, Sa T. Enhancement of growth and salt tolerance of red pepper seedlings (Capsicum annuum L.) by regulating stress ethylene synthesis with halotolerant bacteria containing 1aminocyclopropane-1-carboxylic acid deaminase activity. Plant Physiol Biochem. 2011:49(4):427-34.

32. Glickmann E, Yves D. A critical examination of the specificity of the Salkowski reagent for indolic compounds produced by phytopathogenic bacteria. Appl Environ Microb. 1994;61(2):793-6.

33. Cao L, Qiu Z, You J, Tan H, Zhou S. Isolation and characterization of endophytic streptomycete antagonists of fusarium wilt pathogen from surface-sterilized banana roots. FEMS Microbiol Lett. 2005;247(2):147-52.

34. Bacon CW, Hinton DM, Hinton A Jr. Growth-inhibiting effects of concentrations of fusaric acid on the growth of Bacillus mojavensis and other biocontrol Bacillus species. J Appl Microbiol. 2006;100(1):185-94.

35. Li W, Peng Z, Yang S, Yu J, Huang J, Wu X, et al. Effects of plant growth promoting rhizobacteria on growth and controlling Fusarium-wilt disease of banana seedlings. Acta Horti Sin. 2012;39(2):234-42.

36. Kõljalg U, Nilsson RH, Abarenkov K, Tedersoo L, Taylor AFS, Bahram M, et al. Towards a unified paradigm for sequence-based identification of fungi. Mol Ecol. 2013;22(21):5271-7

37. Ondov BD, Bergman NH, Phillippy AM. Interactive metagenomic visualization in a Web browser. BMC Bioinformatics. 2011. https://doi.org/10. 1186/1471-2105-12-385.

38. Kemp PF, Aller JY. Bacterial diversity in aquatic and other environments: what 16S rDNA libraries can tell us. FEMS Microbiol Ecol. 2004:47(2):161-77.

39. Son SW, Kim HY, Choi GJ, Lim HK, Jang KS, Lee SO, et al. Bikaverin and fusaric acid from Fusarium oxysporum show antioomycete activity against Phytophthora infestans. J Appl Microbiol. 2008;104(3):692-8.

40. Thomas P, Sekhar AC. Cultivation versus molecular analysis of banana (Musa sp.) shoot-tip tissue reveals enormous diversity of normally uncultivable endophytic bacteria. Microb Ecol. 2017;73(4):885-99.

41. Andrade LF, de Souza GL, Nietsche S, Xavier AA, Costa MR, Cardoso AM, et al. Analysis of the ability of endophytic bacteria associated with banana tree roots to promote plant growth. J Microbiol. 2014;52(1):27-34.

42. Lian J, Wang Z, Zhou S. Response of endophytic bacterial communities in banana tissue culture plantlets to Fusarium wilt pathogen infection. J Gen Appl Microbiol. 2008:54(2):83-92.

43. Martínez L, Caballero-Mellado J, Orozco J, Martínez-Romero E. Diazotrophic bacteria associated with banana (Musa spp.). Plant Soil. 2003;257(1):35-47.

44. Marcano IE, Diaz-Alcantara CA, Urbano B, Gonzalez-Andres F. Assessment of bacterial populations associated with banana tree roots and development of successful plant probiotics for banana crop. Soil Biol Biochem. 2016;99:1-20.

45. Sekhar AC, Thomas P. Isolation and identification of shoot-tip associated endophytic bacteria from Banana CV, Grand Naine and testing for antagonistic activity against Fusarium oxysporum f. sp. cubense. Am J Plant Sci. 2015;6:943-54

46. Finhel OM, Castrillo G, Paredes SH, Gonzalez IS, Dangl JL. Understanding and exploiting plant beneficial microbes. Curr Opin Plant Biol. 2017;38:155-63.

47. Sanchez-Canizares C, Jorrin B, Poole PS, Tkacz A. Understanding the holobiont: the interdependence of plants and their microbiome. Curr Opin Microbiol. 2017;38:188-96.

48. Hassani MA, Duran P, Hacquard S. Microbial interactions within the plant holobiont. Microbiome. 2018;6:58.

49. Glick BR, Penrose DM, Li J. A model for the lowering of plant ethylene concentrations by plant growth-promoting bacteria. J Theor Biol. 1998; 190(1):63-8. 